\title{
Speech-Language-Hearing intervention in vestibular rehabilitation with the use of technologies: an integrative literature review
}

\author{
Alanna Stefany de Lima Evangelista ${ }^{1}$ \\ https://orcid.org/0000-0001-6192-3130 \\ Erika Suenya Gomes Cordeiro ${ }^{1}$ \\ https://orcid.org/0000-0001-6167-0743 \\ Gizele Francisco Ferreira do Nascimento' \\ https://orcid.org/0000-0003-0992-9118 \\ Juliana Maria Gazzola' \\ https://orcid.org/0000-0002-9333-1831 \\ Eliene Silva Araújo' \\ https://orcid.org/0000-0002-3675-4651 \\ Erika Barioni Mantello' \\ https://orcid.org/0000-0003-3200-5474
}

Universidade Federal do Rio Grande do Norte - Natal, Rio Grande do Norte, Brasil.

Conflict of interests: Nonexistent

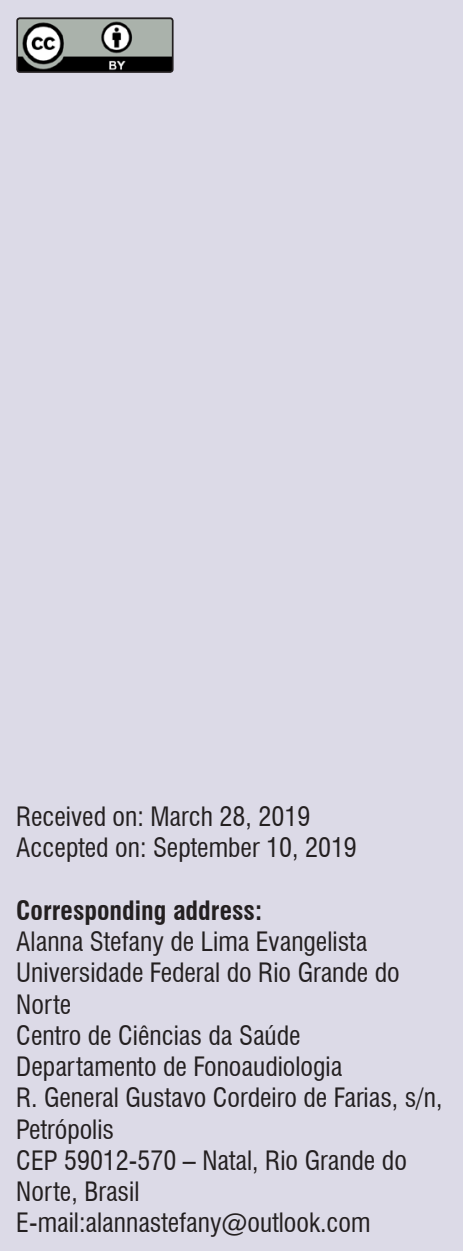

\section{ABSTRACT}

Purpose: to perform an integrative literature review regarding the Speech-LanguageHearing intervention in vestibular rehabilitation with the use of technologies, presenting the most applied ones, as well as their effectiveness and possible biases.

Methods: a search was performed on the PubMed/MEDLINE, LILACS, Scopus and SciELO databases, using as search strategy, the keywords: dizziness OR postural balance AND vestibular rehabilitation. Studies carried out by at least one audiologists and which addressed vestibular rehabilitation with the use of technologies as the study object, were included. The publication period set was from 2008 to 2018. During the evaluation of these articles, a quantitative analysis, a characterization of the included studies and an evaluation of their level of evidence and results were performed.

Results: six articles, published between 2013 and 2018, were chosen. Most studies $(n=4)$ applied Nintendo WiiTM versions during interventions. Among the authors, nine were audiologists. Three studies were clinical trials, two were observational studies without a control group and one was a case study.

Conclusion: it was verified that the Speech-Language-Hearing Therapy has been applying technologies in vestibular rehabilitation interventions. However, publications regarding this modality of therapy are scarce in the literature and still lack robust scientific evidence.

Keywords: Dizziness; Rehabilitation; Virtual Reality; Video Games 


\section{INTRODUCTION}

Postural balance is ensured by three systems that capture inputs from the external environment: vision, proprioception and vestibular. The inputs captured by these systems are sent to the Central Nervous System (CNS), where they are examined, compared and integrated. When the inputs provided to the nervous centers are not coherent with each other because of a damage at any of these structures, whether peripherical or central, a sensorial conflict occurs, leading to dizziness our postural imbalance ${ }^{1,2}$.

Dizziness is a sensation of disruption in the postural balance, which may be defined as an illusion or hallucination of movement and sensation of spatial disorientation of rotational (vertigo) or non-rotational type, as vision instability or postural imbalance. The main forms of dizziness treatment recommended by the otorhinolaryngologist doctor and by rehab professionals are medicine-based, surgical, and the vestibular rehabilitation $(\mathrm{VR})^{2}$.

VR is an efficient physiological therapy method that acts in the vestibular system, potentiates the CNS's neuroplasticity, promotes postural balance recovery and stimulates the natural compensation, adaptation and habituation mechanisms. It is based on body exercise programs or specific physical maneuvers, associated to recommendations about habit changes. The exercises aim to improve the postural balance function and, consequently, improve the individual competent in the execution of everyday activities ${ }^{3}$.

Today, the use of technologies during the therapeutic process has become an ally of health professionals, including the audiologists. Their application in the Speech-Language-Hearing is grounded on different theoretical approaches, whether as a motivational tool or rather as a creative and integrating tool. There are several types of technological tools being used, such as virtual reality, video games and computer-based tools. The effects generated by these tools trigger changes in the brain, which are important to the rehabilitation process ${ }^{4}$.

Virtual reality enables the immersion in an illusory world, where the perception of the environment is modified by an artificial input ${ }^{5}$. The advantage of the virtual reality use in VR is to allow the therapist to provide a large variety of stimuli with higher specificity when compared to traditional methods, presenting sensorial conflicts to the patient in different difficulty levels and at a safe environment ${ }^{6}$.
Video game-based programs for balance retrieval are more enjoyable and engaging to patients than traditional ones, since they promote, in a supplementary manner, interactivity through reactions of postural balance and through the experimentation of a reality that is different from the conventional, frequently adopted in traditional VR therapies ${ }^{7}$.

Most of the researches on the use of these technologies in VR is of physiotherapeutic character. Only a few studies that address the use of these technologies in VR at the Speech-Language-Hearing sphere have been found. Taking that into account, this study aimed to perform an integrative review regarding the SpeechLanguage-Hearing work in VR with the use of technologies. It also aims to discuss the most employed technology types, as well as their efficacy and potential biases.

\section{METHODS}

This study comprehends an integrative literature review of exploratory and descriptive nature. The steps to the elaboration of this review are based on the guide published by Sampaio and Mancinis. The leading question of this study was "Is the Speech-LanguageHearing field applying technologies aimed at the vestibular rehabilitation of individuals with dizziness and postural imbalance?"

To answer this question, a search was made in the PubMed/MEDLINE, LILACS, Scopus and SciELO databases. The search strategy applied was around dizziness OR postural balance AND vestibular rehabilitation. The term vestibular rehabilitation is not a describer indexed in the Medical Subject Heading (MeSH) or in the Health Sciences Descriptors (DecS), however, it was employed as a keyword to restrict the studies containing the research theme.

The determined publication period was from 2008 to 2018, and articles in Portuguese and English were added.

The databases search took place between the months of May and June 2018, and were performed by two pairs of independent researchers, based on the inclusion and exclusion criteria described below.

Studies published in national and international magazines, which were performed with human beings, carried out by at least one audiologists in the team and that presented, as study object, the VR with use of technologies, such as virtual reality, augmented reality, video game and computer games, were included. 
It was excluded articles that did not demonstrate at least one audiologists among the researchers, that used only conventional VR, studies selected by only a pair of researchers and those with scientific evidence lower than level 4, according to the scale proposed by the Oxford Centre for Evidence-based Medicine ${ }^{9}$.

A total of 20161 articles were found, according to all databases listed. After reading their titles, 80 abstracts were chosen for analysis. According to the selection parameters adopted, 14 studies were fully read, from which only six were properly assessed for the review, as shown in the flowchart in Figure 1.

The assessment of the articles found was split into three steps. First, a quantitative analysis of the studies obtained from the employed strategies was carried out; next, a characterization of the articles included was executed and, lastly, the evidence level and their results were evaluated.

\section{Articles found: 2061}

- Pubmed: 1299

- Scielo: 70

- LILACS: 60

- Scielo: 632

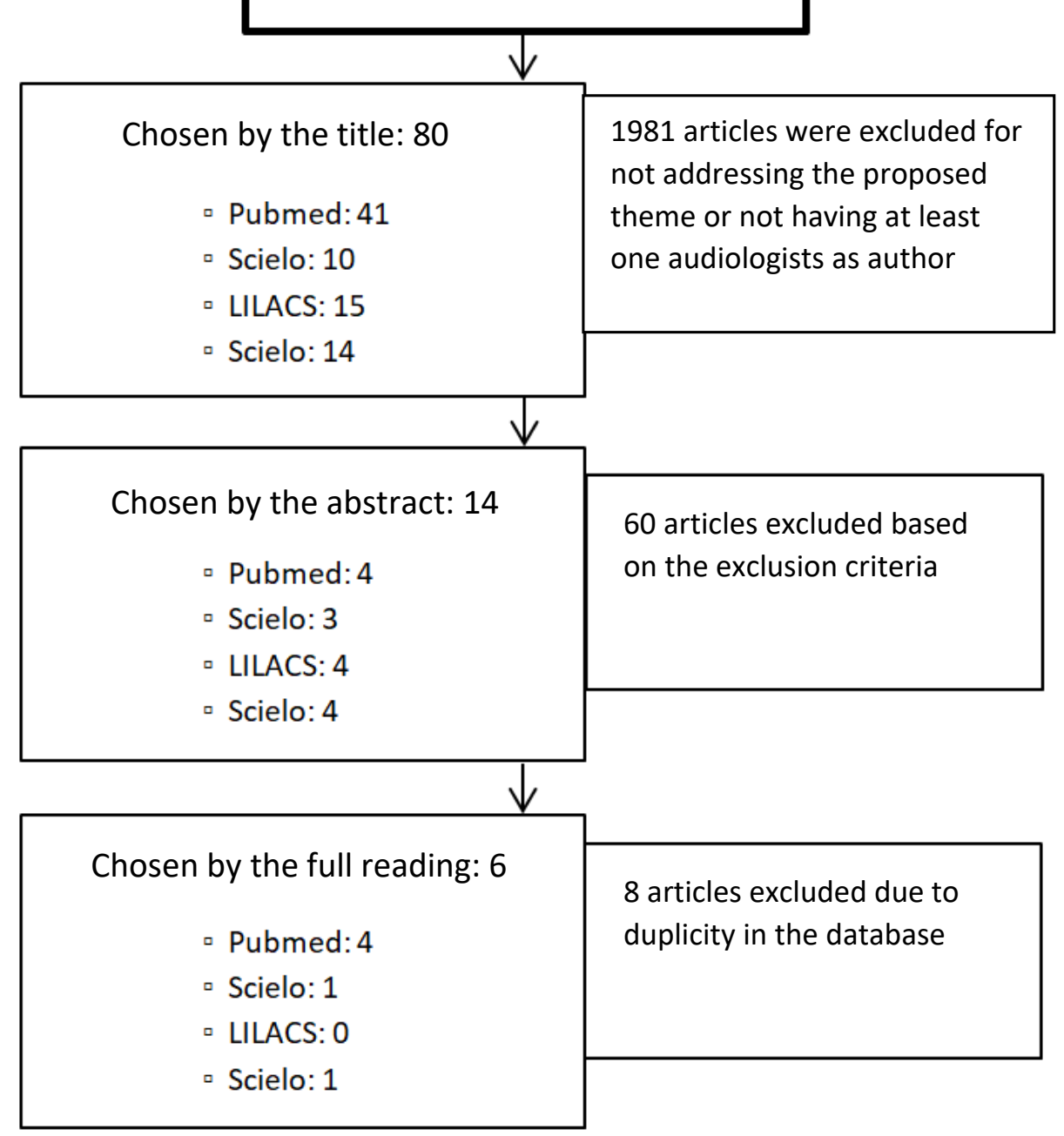

Figure 1. Flowchart of the article selection process 


\section{LITERATURE REVIEW}

Throughout the research, 80 articles were identified from their titles, from which 14 were chosen after reading the abstract and, later, 8 were excluded because of the following dispositions: studies present in more than one database researched; studies that drifted from the proposed theme and those that were not related to the Speech-Language-Hearing intervention. Then, the final sample chosen comprised six articles ${ }^{10-15}$, described in Figure 2.

\begin{tabular}{|c|c|c|c|c|c|c|c|}
\hline AUTHORS/YEAR & N & $\begin{array}{l}\text { TYPE OF } \\
\text { DISEASE }\end{array}$ & $\begin{array}{c}\text { APPLIED } \\
\text { TECHNOLOGIES }\end{array}$ & $\begin{array}{l}\text { PERIOD AND } \\
\text { FREQUENCY OF } \\
\text { THERAPY }\end{array}$ & $\begin{array}{c}\text { TOOL OF EVALUATION } \\
\text { AND RE-EVALUATION } \\
\text { OF THE THERAPEUTIC } \\
\text { OUTCOMES }\end{array}$ & RESULTS & $\begin{array}{l}\text { EVIDENCE } \\
\text { LEVEL** }\end{array}$ \\
\hline $\begin{array}{c}\text { Santos G, Bianca D, } \\
\text { Zeigelboim S, Severia- } \\
\text { no M, Liberalesso P, } \\
\text { Marques J, Cordeiro } \\
\text { M/201710. }\end{array}$ & 28 & $\begin{array}{l}\text { Spinocere- } \\
\text { bellar Ataxia }\end{array}$ & $\begin{array}{c}\text { Nintendo VR Wii } \\
\text { Hand-held Re- } \\
\text { mote; } \\
\text { Wii Balance Board }\end{array}$ & $\begin{array}{c}\text { Twenty sessions; } \\
50 \text { minutes; twice } \\
\text { a week }\end{array}$ & $\begin{array}{l}\text { Dizziness Handicap } \\
\text { Inventory (DHI); Medical } \\
\text { Outcomes Study SF-36 } \\
\text { Intervention; Berg Bal- } \\
\text { ance Scale (BBS) }\end{array}$ & $\begin{array}{l}\text { Consistent improvement } \\
\text { post rehabilitation in the } \\
\text { capacity of using virtual } \\
\text { reality games }\end{array}$ & $2 \mathrm{C}$ \\
\hline $\begin{array}{c}\text { Severiano MIR, Zeigel- } \\
\text { boim BS, Teive HAG, } \\
\text { Santos GJB, Fonseca } \\
\text { VR/2018 }\end{array}$ & 16 & $\begin{array}{l}\text { Parkinson's } \\
\text { Disease }\end{array}$ & $\begin{array}{c}\text { Nintendo Wii; } \\
\text { Wii-Remote; } \\
\text { Wii Balance Board }\end{array}$ & $\begin{array}{l}\text { Twenty sessions; } \\
50 \text { minutes; twice } \\
\text { a week }\end{array}$ & $\begin{array}{l}\text { Dizziness Handicap } \\
\text { Inventory (DHI); Berg } \\
\text { Balance Scale (BBS) }\end{array}$ & $\begin{array}{l}\text { TheTightrope Walk and } \\
\text { Ski Slalom virtual games } \\
\text { showed to be more effi- } \\
\text { cient for this population }\end{array}$ & $2 C$ \\
\hline $\begin{array}{c}\text { Zeigelboim BS, Sou- } \\
\text { za SD, Mengelberg } \\
\text { H, Afonso H, Tei- } \\
\text { veG/2013 } 23^{12} \text {. }\end{array}$ & 4 & $\begin{array}{l}\text { Spinocere- } \\
\text { bellar Ataxia }\end{array}$ & Nintendo Wii & $\begin{array}{l}\text { Ten sessions; } 30 \\
\text { minutes; twice a } \\
\text { week }\end{array}$ & $\begin{array}{c}\text { Berg Balance Scale } \\
\text { (BBS) }\end{array}$ & $\begin{array}{l}\text { Improvement in the coor- } \\
\text { dination of movement and } \\
\text { of postural balance in the } \\
\text { comparison pre and post } \\
\text { VR with virtual reality in } \\
\text { patients with Spinocere- } \\
\text { bellar Ataxia }\end{array}$ & 4 \\
\hline $\begin{array}{c}\text { Phillips JS, Fitzgerald } \\
\text { J, Phillis D, Underwood } \\
\text { A, Nunney I, Bath } \\
\text { A/2018 }\end{array}$ & $\begin{array}{l}\text { G. } \exp .: 21 \\
\text { G. cont.: } 19\end{array}$ & Dizziness & Wii Balance Board & $\begin{array}{c}\text { One hundred and } \\
\text { twelve sessions; } \\
60 \text { minutes; every } \\
\text { day }\end{array}$ & $\begin{array}{c}\text { Dizziness Handicap } \\
\text { Inventory (DHI); Medical } \\
\text { Outcomes Study SF-36 } \\
\text { Intervention }\end{array}$ & $\begin{array}{l}\text { Statistically significant } \\
\text { improvement of postural } \\
\text { balance and life quality }\end{array}$ & $2 B$ \\
\hline $\begin{array}{c}\text { Garcia AP, Ganança } \\
\text { MM, Cusin FS, Tomaz } \\
\text { A, Ganança FF, Caovilla } \\
\text { HH/2013 } \\
\text { 14. }\end{array}$ & $\begin{array}{l}\text { G. } \exp .: 23 \\
\text { G. cont.: } 21\end{array}$ & $\begin{array}{l}\text { Meniere's } \\
\text { Disease }\end{array}$ & $\begin{array}{l}\text { Balance Rehabili- } \\
\text { tation Unit }\end{array}$ & $\begin{array}{l}\text { Twelve sessions, } \\
45 \text { minutes/ twice } \\
\text { a week }\end{array}$ & $\begin{array}{l}\text { Dizziness Handicap } \\
\text { Inventory }(\mathrm{DHI})\end{array}$ & $\begin{array}{l}\text { Improvement of dizziness } \\
\text { through the rehabilitation } \\
\text { of the postural balance } \\
\text { with virtual reality stimuli. }\end{array}$ & $2 B$ \\
\hline $\begin{array}{c}\text { Manso A, Ganan- } \\
\text { ça MM, Caovilla } \\
\text { HH/2016 }\end{array}$ & $\begin{array}{l}\text { G. } \exp .: 20 \\
\text { G. cont.: } 20\end{array}$ & $\begin{array}{c}\text { Peripheral } \\
\text { vestibulopathy }\end{array}$ & $\begin{array}{c}\text { Estímulos visuais } \\
\text { em DVD }\end{array}$ & $\begin{array}{c}\text { Twelve sessions, } \\
40 \text { minutes/ twice } \\
\text { a week }\end{array}$ & $\begin{array}{l}\text { Dizziness Handicap } \\
\text { Inventory }(\mathrm{DHI})\end{array}$ & $\begin{array}{l}\text { Reduction of dizziness } \\
\text { through rehabilitation } \\
\text { of the postural balance } \\
\text { and with the inclusion } \\
\text { of visual stimuli through } \\
\text { digital images }\end{array}$ & $2 B$ \\
\hline
\end{tabular}

Legend: $n$ - number of subjects

* According to the scale proposed by theOxford Centre for Evidence-based Medicine. Available ${ }^{9}$.

Figure 2. Characterization of the articles chosen for the integrative review

For the composition of this study's sample, four articles were chosen from PubMed/MEDLINE, one article from Scielo and on article from Scopus. As for the publication year, there was a variation between the years 2013 and 2018, in which two studies were published in 2013, one in 2015, two in 2017 and one in 2018. Regarding the nationality of the studies, it was verified that five of them were carried out in Brazil and one in the United Kingdom.

The participants age ranges varied from 18 to 70 years old. All the studies had men and women among the participants. There was no statistically significant difference between the demographic characteristics in these studies. The number of participants included at the researchers found was one of the common limitations between the studies. In addition, the age ranges heterogeneity affected the possibility of results comparison. Physiological ageing causes a reduction in postural balance, besides other limitations associated to the senescenceand senility that are not found in young individuals, which may influence the results of the intervention. In the study by Santos et al. ${ }^{10}$, for instance, the age varied from 15 to 70 years old. 
Regarding the medical-etiological diagnosis of the designated articles, the Spinocerebellar ataxia, Parkinson's Disease and Meniere's disease were mentioned.

The Parkinson's Disease is described as a chronic and progressive affliction of the nervous system, characterized by the rigidity, akinesia, bradykinesia, tremor and body instability ${ }^{16}$. According to Severiano et al. ${ }^{15}$, balance alterations are related to the loss of postural reflexes, and this control is directly connected to the muscular and articular proprioception, to the vestibular system and to the vision.

Two out of all chosen studies ${ }^{12,13}$ describe Spinocerebellar Ataxias as a heterogeneous group of neurodegenerative diseases, which are characterized by the presence of progressive cerebellar ataxia. The clinical manifestations commonly observed are the deterioration of the postural balance and of the motor coordination, along with ocular disturbances. Santos et al. ${ }^{10}$ describe that most cases of this disease is congenital, although certain times it occurs because of traumas that are external to the CNS. Patients who suffer from this condition are prone tolesions resulting from falls due to postural imbalance.

Another affliction characterized by the presence of dizziness, in addition to tinnitus and hearing loss, is the Meniere's Disease, which is represented by paroxysmal episodes without CNS involvement. It has the endolymphatic hydrops as its physiopathological base, caused by an increase in the endolymphatic pressure ${ }^{14}$.

The VR with virtual reality in these types of diseases must be carefully pondered. The use for all types of patients with all forms of vestibular disorder is not appropriate ${ }^{15}$. The use of video games during rehabilitation was demonstrated in a few studies ${ }^{11}$, however, there is little discussion about the selection of games. Even though there are no evidences related to the side effects of the use of virtual reality, an individualized analysis is recommended in order to provide the patients with the highest benefit possible.

Virtual reality began to be adopted by the end of the $20^{\text {th }}$ century, as a rehabilitation tool for patients with motor and cognitive disabilities. Virtual rehabilitation may be characterized as the use of computerized technologies allied to the concepts of functional physical rehabilitation that, through virtual games, simulate the execution of activities to the patient in a ludic and innovative manner, which enhances the therapeutic possibilities ${ }^{17}$.
The technologies applied in VR found in the chosen articles $^{10-15}$ were: visual stimuli projected on a screen, Wii Fit Plus, Balance Rehabilitation Unit, Nintendo Wii, Wii-Remote, Wii Balance Board and Wii Hand-Held Remote.

A predominance of electronic devices that permeates the rehabilitation by using virtual reality was verified. It was also verified a predominance of the use of the Wii Balance Board.

The Nintendo Wii console is one of the most used non-immersive virtual reality platforms today in physical-functional rehabilitation. It is a low-cost and easy-to-access technology. The multisensorial activities promoted by the video game enable the user to receive, interpret and integrate stimuli, becoming capable of interacting with the environment and with other individuals ${ }^{15}$.

The Wii Fit Plus is one of the games used on the Nintendo Wii platform. The game simulates circular movements of the pelvis, rotation and weight transference exercises, aiming changes in the balance and instability of the body. A study ${ }^{12}$ used the extensions Bird's -Eye Bull's-Eye, Big Top Juggling and Hula Hoop, allied to a balance board (Wii Balance Board) to reach the therapeutic goals.

The Wii Balance Board is a platform that measures the applied force and sensibly perceives the changes in balance, through pressure sensors. The sensors present in the platform are responsible for the interface between the machine and the user ${ }^{12}$.

The Balance Rehabilitation Unit (BRU ${ }^{\mathrm{TM}}$ ) has been employed to rehabilitate patients with dizziness and associated symptoms through visual stimuli projected on a pair of virtual reality glasses. It presents three modules: posturography, rehabilitation of the postural balance, and postural training games. The $\mathrm{BRU}^{\mathrm{Tm}}$ posturography module provides information about the pressure center position of the patient through the measurements of the stability limit area, body oscillation speed, and pressure center area. The second module, of balance rehabilitation, recreates situations that lead to dizziness or vertigo, assisting in the vestibular compensation. The third module is composed of interactive games aimed at the training of the postural balance, of the limit, and of the muscular stability and coordination, in different motor proposals and difficulty levels ${ }^{18}$.

The use of images projection to introduce stimuli of slow ocular fixation and pursuit, saccadic and optokinetic movements during VR, is considered to be an 
accessible instrument, both for the patient as well as for the therapist, due to its low cost and easy handling, in addition of easing the clinical practice and assisting in the adherence to the therapy in the acquisition of body stability and in the improvement of the patient's emotional state ${ }^{15}$.

The Wii-Remote is a manual control with sensors responsible for detecting movements made by the patient regarding acceleration in three dimensions, with the goal of generating an augmented proprioception, just like the Wii Hand-Held Remote, a portable console of the Nintendo Wii that also enables the execution of virtual reality games ${ }^{10}$.

The patients of the six studies ${ }^{10-15}$ underwent, in average, four months in intervention, all of them with at least two weekly rehabilitation sessions. Some articles describe that the duration and number of sessions may be variable according to the type of disease presented by the patient, as well as by the comorbidities, age, motivation and the concomitant use of multiple medicines ${ }^{10,15}$. In relation to medicines, it is known that they may present more than one type of action, some may act positively in the reduction of vestibular symptoms during dizziness crisis, others may delay the vestibular compensation process or even, in cases of medication association, result in complications of vestibular symptoms as a side effect. The prescription and control of the medication effects need to be rigorously carried out and monitored by the otoneurologist, given that they may influence in the habituation mechanisms of the vestibular system and, consequently, in the therapy results ${ }^{19}$.

For the assessment of the therapeutic outcomes, the most applied tool was the Dizziness Handicap Inventory $(\mathrm{DHI})^{20}$, although it was also used the Visual Vertigo Analogue Scale ${ }^{21}$, the Berg Balance Scale (BBS) ${ }^{22}$ and the Medical Outcomes Study SF-36 Intervention ${ }^{23}$.

The $\mathrm{DH}^{20}$ is a questionnaire composed by 25 questions that evaluates the self-perception of the disabling effects caused by dizziness, divided into physical, emotional and functional domains. The Visual Vertigo Analogue Scale ${ }^{21}$ measures the intensity of symptoms like dizziness, vertigo and imbalance in a millimetric scale that ranges from 0 to 10 . The $\mathrm{BBS}^{22}$ assesses the patient's performance in 14 postural balance control activities. And the Medical Outcomes Study SF-36 Intervention ${ }^{23}$ is a of 36 -items questionnaire that assesses the life quality.

The use of these questionnaires and scales, which are subjective tools, to assess the intervention results, instead of the use of objective tests, was a limitation verified in a few studies ${ }^{10-13,15}$. An article ${ }^{14}$ employed posturography as a therapy evaluation method, which demonstrated significantly higher values of the stability limit area of the patients. The use of tests enables to monitor, through objective measures, the evolution of the vestibular compensation of the individual with peripheral or central vestibular disfunction, which means, it quantifies the improvement of the vestibular function and of the postural balance.

The designated studies ${ }^{10-15}$ describe that the use of technologies in VR displays expressive results regarding the maintenance ofpostural balance and march, and add that the use of virtual reality provides an accentuated improvement in the life quality of patients with imbalance.

The use of technologies in therapy enables the immersion in an illusory world, where the perception of the environment is modified by an artificial stimulus, generating sensorial conflict and changing the gain of the vestibulo-ocular reflex. Studies by Donáet al. ${ }^{24}$ have demonstrated that VR with the use of virtual realities, when done in a customized manner based on the patient's complaint, on the clinical condition and on the vestibular evaluation findings, presented better results than the conventional therapy for $85 \%$ of the participants.

The use of electronic games enables to recreate environmental changes in visual, auditory, vestibular and somatosensorial stimuli in order to adjust the vestibulo-ocular and vestibulospinal reflex involved in postural balance ${ }^{24}$. However, a regular difficulty found in researches that involve the intervention with technologies is that there is a scarcity of game selection protocols and delimitators of therapy time with scientific proof in literature.

The Wii Fit Plus games have demonstrated to be useful in the balance rehabilitation of elderly patients ${ }^{20}$. The games promote saccadic and optokinetic stimuli, ocular pursuit movements and a more refined control of the pressure center, in addition of training joint response strategies through the Wii Balance Board platform, enabling a significant improvement in postural balance. The improvements are attributed to the neuroplasticity, displaying a habituation of the vestibular system to the repeated exercises ${ }^{10,25,26}$.

The results among groups that applied technological tools and those that applied conventional VR did not present a statistically significant difference, although it was verified a reduction in dizziness, improvement of 
life quality and postural balance among individuals in general, before and after the interventions. These tools allow the patient to interact with the virtual environment proposed and to receive visual feedback in relation to changes in his or her movements, therefore creating strategies to recover and/or preserve the postural balance ${ }^{13-15}$.

A study ${ }^{10}$ concluded that, in pathologies of neurological base, such as the ones listed in this study, a full functional recovery of the balance through VR is not expected, whether it is conventional or through the use of technological tools. However, rehabilitation is the adequate conduct, and its results, although minimum, shall be interpreted as positive, because they help to slow down the evolution of the symptoms (central) and to improve the life quality of the patients.

Five out of the six aforementioned articles ${ }^{10,11,13-15}$ show that the most mentioned feedbacks by the patients demonstrate a significant improvement in life quality and in the drive to perform the exercises. The increase in the encouragement to perform rehabilitation is also mentioned as a benefit, in addition to the balance and posture correction, improvement in the locomotion and in the functionality of lower and upper limbs.

According to the Oxford scale ${ }^{9}$, the articles that were part of this research presented levels of evidence 2B, $2 \mathrm{C}$ and 4 . Four of them had comparative character with experimental and control groups, and two of them were studies of observation of therapeutic results without a control group.

It was observed that, according to the chosen studies, most of the authors were audiologists $(n=9)$ and that most part of the other professionals had educational background in the health area (Table 1).

During the literature selection process, it was observed a large number of articles published by physiotherapists, which could not enter this study due to the inclusion and exclusion criteria employed. It was verified a scarcity of researches about

Table 1. Academic background of the authors of the articles chosen for the integrative review

\begin{tabular}{cc}
\hline Academic background & Number of authors \\
\hline Speech-Language-Hearing Therapy & 9 \\
Physiotherapy & 3 \\
Otorhinolaryngology & 6 \\
Neurology & 2 \\
Neuroscience & 1 \\
Physical Education & 1 \\
Statistics & 1 \\
\hline Total & 23 \\
\hline
\end{tabular}

Speech-Language-Hearing involving the use of VR technologies in individuals who presented dizziness and postural imbalance, justifying the need for more publications, given that the researched studies have demonstrated several benefits.

The use of technologies allows a larger control and variety of stimuli when compared to conventional therapy. In addition, it promotes motivation and, consequently, more adherence of the patients to the rehabilitation program, with consequent possibility of reduction in the number of intervention sessions. However, technological equipment require an investment in order to be purchased, especially in cases of public health services, or associated to university centers of SpeechLanguage-Hearing, responsible for the free-of-charge care provided to the population with vestibular disorders and also for part of the production of scientific publications related to it. The conventional VR, by itself, is effective when it comes to results. However, technological tools enhance these effects, as it can be verified according to literature ${ }^{10-15}$.

Regarding the scarcity of publications addressed by the Speech-Language-Hearing field, it is believed that the Otoneurology, a subarea of Audiology, still is little studied in Speech-Language-Hearing graduation courses, with reduced learning workload, which ends up limiting the possibility of clinical work of SpeechLanguage-Hearing undergraduates in this field and, consequently, reducing the number of audiologists interested in carrying out researches when compared 
to the number of Physiotherapy professionals, given that VR is not a work area exclusive to the SpeechLanguage-Hearing, but a multidisciplinary area.

\section{CONCLUSION}

The Speech-Language-Hearing Therapy has been applying technological tools in VR interventions. However, publications related to this therapy modality are scarce and are still short of robust scientific evidences.

It was verified that virtual reality was the most employed type of technology, through the Nintendo Wii equipment. It was also possible to observe the occurrence of positive outcomes due to the use of technologies during VR, which comprehends an improvement in postural balance with an impact on the quality of life.

Further studies, carried out by Speech-LanguageHearing therapists about VR with the employment of new technologies in comparison to the traditional therapy, in different age ranges, with the use of objective tools associated to subjective ones, to monitor the results after the intervention, are necessary.

\section{ACKNOWLEDGMENTS}

This study was carried out with the support of the Coordination of Higher Education Personnel Improvement (Coordenação de Aperfeiçoamento de Pessoal de Nível Superior - CAPES) - Brazil - Funding code 001.

\section{REFERENCES}

1. Maia FCZ. Elementos práticos em otoneurologia. 2a ed. Rio de Janeiro: Editora Revinter; 2011.

2. Holmes S, Padgham ND. A review of the burden of vertigo. J Clin Nurs. 2011;20(19-20):2690-701.

3. Ramos S, Ramos RF, Ganança CF, Ramos BF. Reabilitação vestibular. In: Neto SC, Júnior JFM, Martins RHG, Costa SS (eds). Tratado de otorrinolaringologia e cirúrgia cervico facial. $2 a$ ed. São Paulo: Editora Roca; 2011. p.551-62.

4. Schiavinato AM, Baldan C, Melatto L, Lima LS. Influência do WII Fit no equilíbrio de paciente com disfunção cerebelar: estudo de caso. J Health Sci Inst. 2010;28(1):50-2.

5. Garcia AP, Gananca MM, Cusin FS, Tomaz A, Ganança FF, Caovilla HH. Reabilitação vestibular com realidade virtual na doença de Meniere. Braz J Otorrinolaringol. 2013;79(3):366-74.
6. Cakrt O, Chovanec M, Funda T, Kalitová P, Betka $J$, Zverina $E$ et al. Exercise with visual feedback improves postural stability after vestibular schwannoma surgery. Eur Arch Otorhinolaryngol. 2010;267(9):1355-60.

7. Brumels KA, Blausius $T$, Cortright $T$, Oumedian D, Solberg B. Comparison of efficacy between traditional and vídeo game based balance programs. ClinKinesiol J Am Kinesiotherapy Assoc. 2008;62(4):26-31.

8. Sampaio RF, Mancini MC. Estudos de revisão sistemática: um guia para síntese criteriosa da evidência científica. Rev Bras Fisioter. 2007;11(1):83-9.

9. Oxford Centre for Evidence-Based Medicine. Levels of Evidence. [cited 2018 Jun 30]. Available from: https://www.cebm.net/2009/06/oxfordcentre-evidence-based-medicine-levels-evidencemarch-2009/.

10. Santos G, Bianca D, Zeigelboim S, Severiano $M$, Liberalesso $P$, Marques $J$ et al. Feasibility of virtual reality-based balance rehabilitation in adults with spinocerebellar ataxia: a prospective observational study. Hearing Balance Commun. 2017;15(4):244-51.

11. Severiano MIR, Zeigelboim BS, Teive HAG, Santos GJB, Fonseca VR. Effect of virtual reality in parkinson's disease: a prospective observational study. Arq Neuro-Psiquiatr. 2018;76(2):78-84.

12. Zeigelboim BS, Souza SD, Mengelberg $H$, Afonso $\mathrm{H}$, Teive $\mathrm{G}$. Vestibular rehabilitation with virtual reality in spinocerebellar ataxia. Audiol Commun Res. 2013;18(2):143-7.

13. Phillips JS, Fitzgerald J, Phillis D, Underwood A, Nunney I, Bath A. Vestibular rehabilitation using video gaming in adults with dizziness: a pilot study. J Laryngol Otol. 2018;132(3):202-06.

14. Garcia AP, Ganança MM, Cusin FS, Tomaz A, Ganança FF, Caovilla HH. Vestibular rehabilitation with virtual reality in ménière's disease. Braz $\mathrm{J}$ Otorhinolaryngol. 2013;79(3):366-74.

15. Manso A, Ganança MM, Caovilla HH. Vestibular rehabilitation with visual stimuli in peripheral vestibular disorders. Braz J Otorhinolaryngol. 2016;82(2):232-41.

16. Souza CFM, Almeida HCP, Souza JB, Costa PH, Silveira YSS, Bezerra JCL. A doença de parkinson e o processo de envelhecimento motor: uma revisão de literatura. Rev Neurociênc. 2011;19(4):718-23. 
17. Batista JS, Wibelinger LM, De Marchi ACB, Schneider RH, Pasqualotti A. Reabilitação de idosos com alterações cognitivas através do videogame nintendo wii. RBCEH. 2012;9(2):293-9.

18. BRUTM. Unidade de Reabilitação do Equilíbrio. Manual do usuário - Versão 1.0.7. Versão do Software: 1.3.5.0. Uruguai: Medicaa; 2006.

19. Ganança MM. Farmacoterapia racional da vertigem. In: Ganança MM (ed). Vertigem tem cura? O que aprendemos nestes últimos 30 anos. São Paulo: Lemos, 1998. p. 227-36

20. Castro AS, Gazzola JM, Natour J, Ganança FF. Versão Brasileira do Dizziness Handicap Inventory. Pró-Fono R Atual Cient. 2007;19(1):97-104.

21. Whitney SL, Herdman SJ. Physical therapy assessment of vestibular hypofunction. In: Herdman SJ (ed). Vestibular rehabilitation. 3a ed. Philadelphia: FA. Davis; 2007. p. 272-99.

22. Myamoto ST, Lombardi Jr I, Berg KO, Ramos LR, Natour J. Brazilian version of the Berg balancescale. Braz J Med Biol Res. 2004;37(9):1411-21.

23. Ware JE Jr, Sherbourne CD. The MOS 36-item shortform health survey (SF-36): I. conceptual framework and item selection. Med Care. 1992;30(6):473-83.

24. Doná F, Araujo JPF, Maia DAR, Alves AM, Kasse CA. Jogos eletrônicos na reabilitação do equilíbrio corporal em idoso com doença vestibular: caso clínico. Rev Univ Vale do Rio Verde. 2014;12(1):693-702.

25. Laver K, George S, Thomas S, Deutsch JE, Crotty M. Cochrane review: virtual reality for stroke rehabilitation. Eur $\mathrm{J}$ Phys Rehabil Med. 2012;48(3):523-30.

26. Nicholson VP, McKean M, Lowe J, Fawcett C, Burkett B. Six weeks of unsupervised nintendo wii fit gaming is effective at improving balance in independent older adults. J Aging Phys Act. 2015;23(1):153-8. 